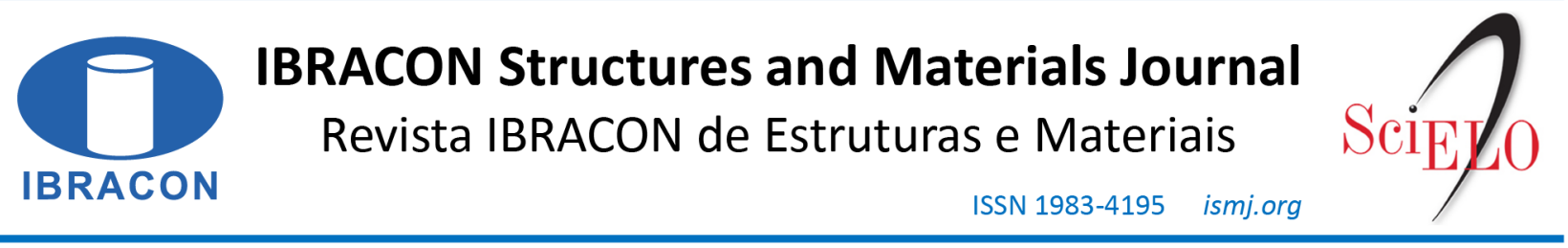

ORIGINAL ARTICLE

\title{
Flexure shear capacity of prestressed hollow core slabs
}

\section{Resistência à flexo-cortante de lajes alveolares protendidas}

Bruna Catoia $^{\mathrm{a}}$ (D)
Arthur Lima Rocha $^{\mathrm{a}}$ (D)
Marcelo de Araújo Ferreira $^{\mathrm{a}}$ (D)

${ }^{a}$ Universidade Federal de São Carlos - UFSCar, Departamento de Engenharia Civil, São Carlos, SP, Brasil

Received 16 October 2019

Accepted 28 September 2020

\begin{abstract}
Provided that the anchorage capacity is guaranteed at the supports, the bearing capacity of hollow core slabs depends on the shear capacity of the pretensioned concrete webs, wherein the critical section is in a region between $\mathrm{h}$ and $2 \mathrm{~h}$ from the support. For line loads acting within $2 \mathrm{~h}$ to $6 \mathrm{~h}$ from the supports, especially for shallow slabs $150 \mathrm{to} 200 \mathrm{~mm}$ deep, it is likely to have flexure-shear cracks within the transfer region, wherein the bearing capacity is highly affected by the actual prestressing forces at the critical section. Therefore, one of the major questions pondered by structural engineers is to determine the effective amount of prestressing force that affects the shear resistance mechanism near to the support. According to ABNT NBR 14861:2011, the shear capacity is based on the flexure-shear mechanism, wherein the shear strength is a sum of the tensile concrete strength in the slab webs plus the contribution of the prestressing forces at the critical section, wherein a coefficient of 0.15 is considered. However, in both codes NBR 14861 and NBR 6118 it is required that this coefficient 0.15 should be further multiplied by an additional reduction factor in order to take into account the effect of the transmission length near to the support. Considering the current revision of the NBR 14861, this paper presents a theoretical-experimental comparison from standard shear tests of hollow core slabs with nominal depths from 150 to $200 \mathrm{~mm}$ carried out in different research at NETPre-UFSCar. Based on the analytical study of each term of the equation for the flexure-shear capacity, it has been observed that the coefficient 0.15 provides a conservative limit for the contribution of the actual prestressing force. Therefore, there is no need to apply any additional reduction factor in order to guarantee a safe design limit for the shear capacity.
\end{abstract}

Keywords: hollow core slabs, precast concrete, flexure-shear, shear capacity.

Resumo: A resistência ao cisalhamento das lajes alveolares protendidas sem armadura transversal é influenciada por diferentes fatores, como a altura útil da laje, a largura total das nervuras dos alvéolos, a resistência à tração do concreto e a tensão da protensão efetiva na seção crítica. A equação recomendada na NBR 14861:2011 está associada ao mecanismo flexo-cortante que ocorre na situação da presença de fissuração por flexão na laje alveolar fora da região do comprimento de transferência próxima aos apoios, sendo obtida pela soma da contribuição da seção transversal de concreto e da contribuição da força de protensão efetiva na região crítica próxima ao apoio. No caso da expressão normativa em questão, a parcela decorrente da contribuição da protensão é considerada multiplicando-se a tensão de protensão por um fator redutor $(0.15)$ com a intenção de considerar a tensão atuante efetiva na seção crítica para a resistência à flexocortante. No entanto, nos textos normativos em vigência da NBR 14861:2011 e NBR 6118:2014, além desse fator de redução presente no equacionamento, é prescrita redução adicional na tensão de protensão com o intuito de considerar o efeito da protensão efetiva no comprimento de transferência. Assim, este artigo apresenta um estudo do fator redutor de multiplicação (0.15) da tensão de protensão na equação da resistência à flexo-cortante, baseado na comparação de resultados de ensaios padronizados de cisalhamento em lajes alveolares protendidas realizados em pesquisas no NETPreUFSCar. A partir do confronto dos resultados experimentais com as previsões teóricas, estudando os termos analíticos da equação em questão, foi possível demonstrar que o fator de redução 0.15 já representa um limite inferior para a contribuição da força atuante de protensão na seção crítica da região próxima ao apoio e, portanto, já considera o efeito da variação da protensão efetiva no comprimento de transferência, não necessitando de fatores adicionais.

Palavras-chave: lajes alveolares, concreto pré-moldado, flexo-cortante, capacidade ao cisalhamento.

How to cite: B. Catoia, A. L. Rocha, and M. A. Ferreira, "Flexure shear capacity of prestressed hollow core slabs", Rev. IBRACON Estrut. Mater., vol. 14, no. 5, e14507, 2021, https://doi.org/10.1590/S1983-41952021000500007

Corresponding author: Bruna Catoia. E-mail: bcatoia@yahoo.com.br

Financial support: CNPq and the companies Cassol, Lajeal and Leonardi.

Conflict of interest: Nothing to declare. 


\section{INTRODUCTION}

The use of precast systems provides an effective improvement for the site construction, with a higher rationalization of the production processes and better quality control of the final building systems. Worldwide, hollow core slabs are the main product within the precast concrete industry. This trend is due mainly to a combination of high structural performances with standardized production methods, with choice of depth and capacity, speed of construction, environmental friendliness without the need for molding and propping on site. Hollow core slabs are produced in casting beds with lengths from 100 to 150 meters, wherein strands positioned in one or two rows within the bottom flange area, aligned with the webs, are pretensioned from 1000 to $1500 \mathrm{MPa}$, without the presence of transverse reinforcement. The first prestressed hollow core slabs produced in Brazil were 150, 200 or $265 \mathrm{~mm}$ in thickness.

According to Lindström [1], the effective prestressing stress that contributes to the shear capacity depends on the transmission length at the slab ends, which also depends on the bond stresses and level of prestressing and type of strand or wire. For the flexure-shear mechanism, wherein there is a possibility of occurrence of bending cracks within $2 \mathrm{~h}$ from $6 \mathrm{~h}$ from the slab support, it is essential that the anchorage capacity is secured in order to avoid any failure by bond-slip at the supports. For detailed analysis, the design value for shear force needs to be checked against the design shear capacity at all critical points in the region of cracked in bending for the given value of design load, wherein the bending moment at a specific position needs to be increased due to the inclined shear flexure crack. In the presence of imposed concentrated loads, also according to Lindström [1], there is a real possibility of occurrence of interaction between flexure-shear and bending mechanisms, wherein they cannot be utilized at their respective maximum capacities.

According to the Brazilian code of practice for hollow core slabs NBR 14861 [2], the shear capacity is based on the flexure-shear mechanism of prestressed concrete slabs with and without structural toppings according to the FIB Bulletin 6 [3] for hollow core slabs, which coincides with the Brazilian code of practice for structural concrete NBR 6118 [4], both inspired in the CEB-FIP Model Code 1978 [5]. As explained by Marquesi [6], this expression was modified from early expressions presented by Walraven and Mercx [7], based on experimental studies on rectangular beams and solid slabs elements, considering the main parameters that affect the shear capacity. Within the normative documents NBR 14861 [2] and NBR 6118 [4], the coefficient 0.15 that affects the actual prestressing force (after losses) needs to be multiplied by an additional reduction factor in order to take into account the effect of the transmission length for the shear capacity mechanism at the support region of the slab.

Considering the current revision of the NBR 14861, this paper presents an experimental-theoretical comparison from results of standard shear tests of hollow core slabs with depths varying from 150 to $200 \mathrm{~mm}$, which were carried out at NETPre-UFSCar, analyzing the contribution of each parcel of the expression for the flexure-shear capacity in order to verify if the coefficient 0.15 is enough to consider the contribution of the actual prestressing force or if there is still the need to apply any additional reduction factor in order to take in account the effect of the transmission length for the flexure-shear capacity.

\section{LITERATURE REVIEW}

\subsection{Failure mechanisms}

In general, hollow core slabs can present different failure mechanisms: loss of anchorage due to bond-slip of the tendons; tension failure due to shear at the critical point in the web; shear in a cracked region (with combined effects of shear, flexure, and bond-slip); combined effects of shear and torsion (in elements that are not perfect planes); flexure (ULS), with great possibility, close to failure, strand slip near to the support; interaction of bending and shear mechanisms.

From several tests, Kong et al. [8] concluded that the failure mode is strongly affected by the relationship between the span subjected to shear $\left(a_{v}\right)$ and the effective height $(d)$. Depending on the type of applied loading, a given failure mechanism will prevail over the other one, or there might be a combination of these two mechanisms.

In Figure 1 the main failure modes can be observed, which are described as follows. 


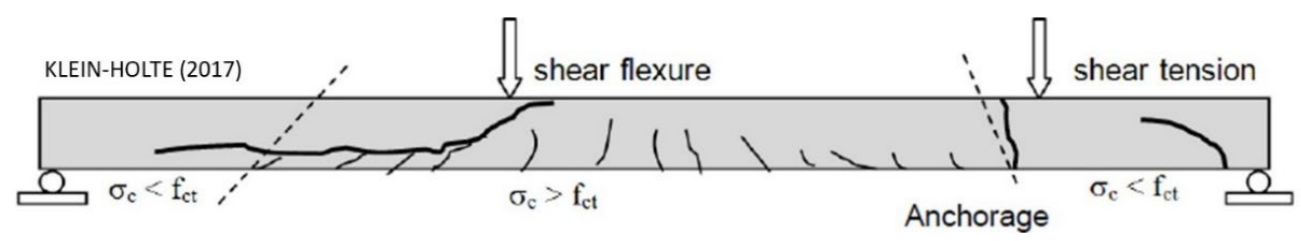

Figure 1. Main failure modes in hollow core slabs [9].

\subsubsection{Shear failure}

The tension shear failure corresponds to an important design criterion for prestressed hollow core slabs. Although the failure mechanism is quite clear, it is difficult to accurately determine the tensile strength according to the theoretical consideration. Thus, it was developed a standard test method to determine the tension shear capacity as well as to gain greater knowledge concerning to different parameters related to the performance of the slabs.

In that cases where the concrete tensile strength is higher than the normal stresses at the bottom surface of prestressed hollow core slabs, without flexural cracks, it is possible to occur an inclined shear crack in the web (Figure 2). The diagonal crack spreads in both directions, ascending and descending, and results in a brittle failure.
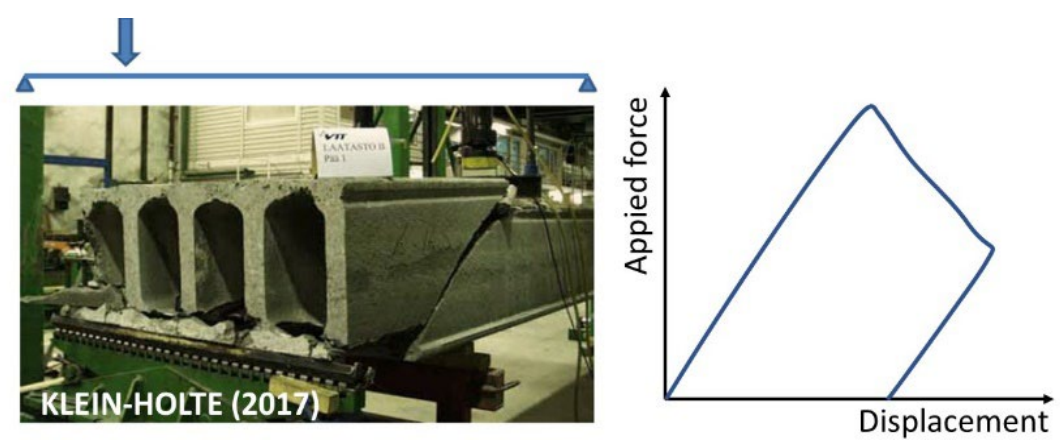

Figure 2. Shear Main failure.

The crack is usually formed in the region where the favorable influence of the vertical normal stress caused by the support reaction [10], and the prestressing force has not yet fully developed. This mechanism characterizes a type of brittle failure. Thus, a crack in the web close to the support can usually lead to tension shear failure due to the fact that the webs of the prestressed hollow core slab are generally very narrow, and there is no shear reinforcement.

\subsubsection{Flexure failure}

When the slab is subjected to positive bending moments generating normal stresses in the lower fibers that are higher than the concrete tensile strength, then bending cracks will occur on the bottom surface of the slab. Provided that no compression failure occurs in the concrete at the top fibers of the slab section, there will be a ductile failure.

\subsubsection{Flexure-shear failure}

Considering a slab subjected to shear with the presence of bending cracks, the distribution of tangential stresses along the section leads to an increase of tension in the bottom fibers of the slab, in the region of the strand, resulting in an interaction between flexural cracks and diagonal shear cracks. Thus, in regions where shear and bending mechanisms interact, bending cracks can propagate to the inclined shear cracks, and the failure mechanism is not always well defined because it can result from the interaction or combination of mechanisms (Figure 3). 

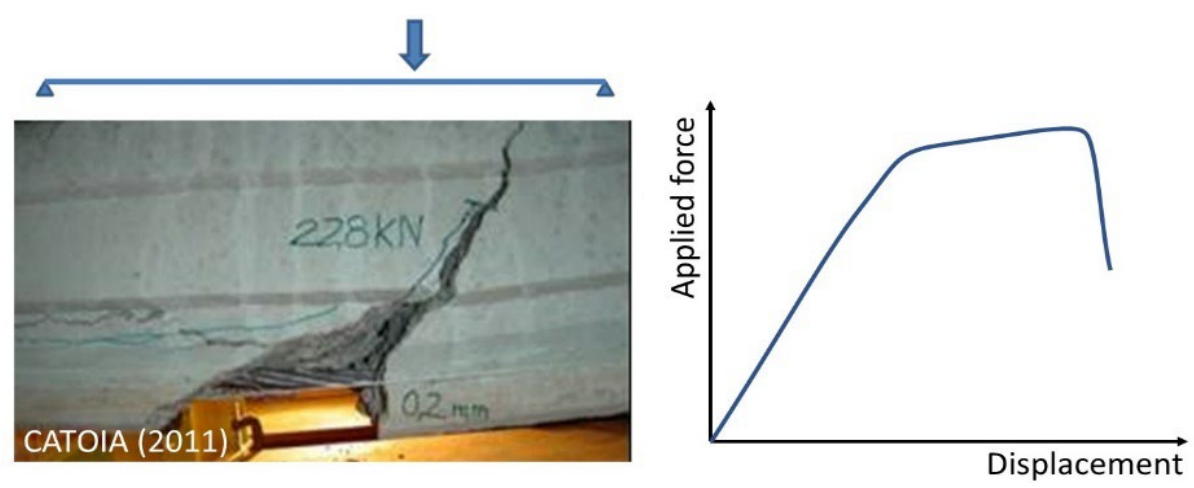

Figure 3. Failure due to interaction between bending moment and shear.

\subsubsection{Anchorage failure}

The required length for transferring the entire prestressing force to the concrete is called transmission length ( $\left.l_{\mathrm{bpt}}\right)$. Along this length, the prestressing force develops approximately according to a parabolic function, as can be seen in Figure 4.
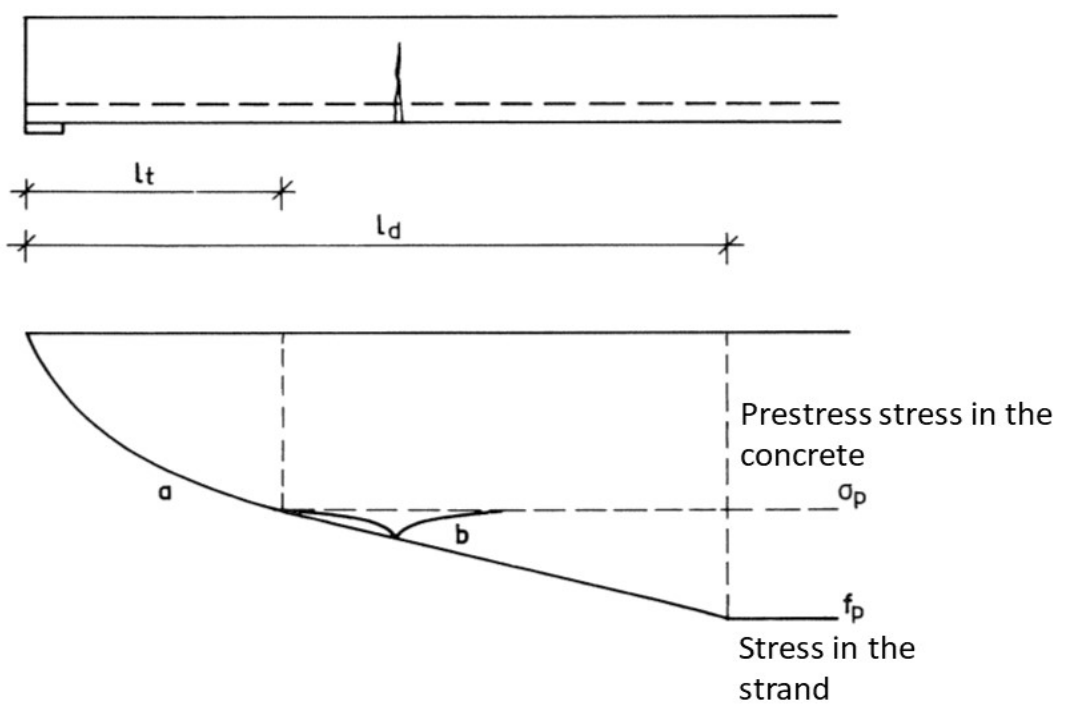

Figure 4. Critical situation of cracking in the anchorage failure [7].

The transfer of prestress along the transmission length is essential for the structural behavior of hollow core slabs. The bond-slip of the tendons must be measured to control whether the required bond strength has been exceeded. The maximum allowed slip depends on the allowed transmission length.

According to Walraven and Mercx [7], if somewhere along the transmission length (region a, Figure 4), a flexural crack appears, it will be difficult to increase the tension in the steel, due to the limit state of equilibrium that exists in that area. If the crack occurs outside the transmission length, an increase in the steel tension is possible. On both sides of the crack (region b), the steel tension is increased over a certain length as long as it is sufficient to transmit the additional strength in the tendons by the bond stress. However, if the steel stress due to cracking is very large and invades the region where the prestressing stress is not fully transferred to the concrete (region a, in Figure 4), the equilibrium along the transfer region is disturbed, causing the slip of the tendons. If the distance from the end of the element is large enough, the ultimate tension in the tendons can be achieved. This distance is called the development or regularization length $\left(l_{d}\right)$. A typical force versus displacement curve for an anchorage failure mechanism is illustrated in Figure 5. 

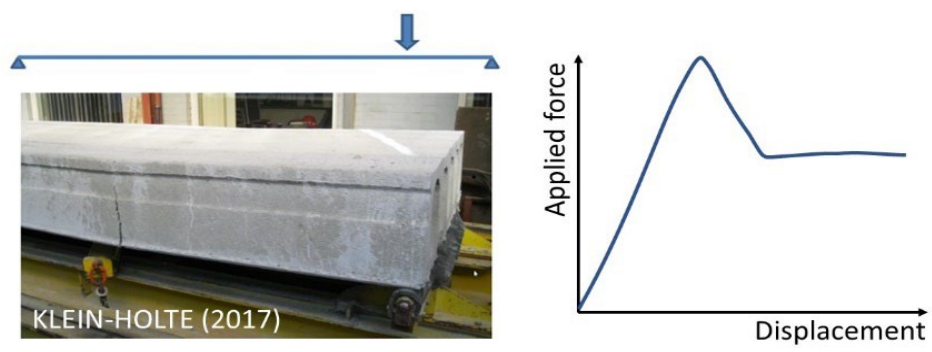

Figure 5. Critical situation of cracking in the anchorage failure [9].

\subsection{Parameters that affect flexure-shear mechanisms}

The interaction of shear and flexure mechanisms is difficult to be analyzed due to the complex redistribution of stresses along the section after the start of concrete cracking. Thus, for the calculation of shear strength in cracked regions, empirical equations were developed and calibrated through experimental tests in order to consider the most significant variables such as: the concrete tensile strength and the actual axial stress (due to prestressing).

The main parameters that affect the shear strength in cracked regions are: concrete tensile strength; longitudinal reinforcement rate; scale factor; influence of axial forces (due to prestressing), type, and the aggregate size.

The influence of the concrete tensile strength, reinforcement, scale factor, and prestress are considered in the equation recommended by NBR 14861: 2011 [2], according to Figure 6.

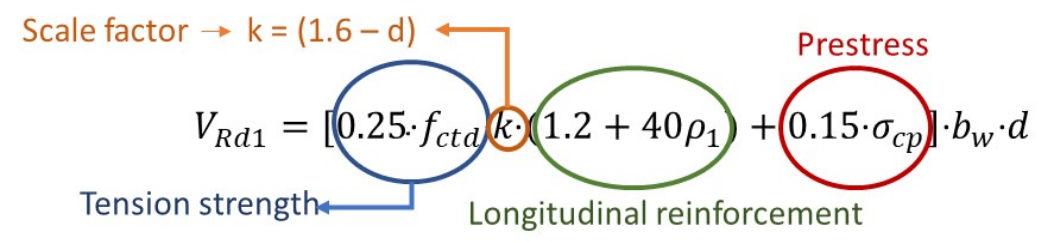

Figure 6. Identification of the parameters considered in the equation recommended by NBR 14861 [2].

\subsubsection{Contribution of the shear transfer actions}

According to Cavagnis et al. [11], the contribution of the basic shear transfer actions along the critical crack in elements without transverse reinforcement can be divided into four parts:

1. Part related to the concrete residual tensile strength contribution $\left(\mathrm{V}_{\mathrm{Res}}\right)$;

2. Part related to the dowelling action of longitudinal reinforcement $\left(\mathrm{V}_{\text {dowel }}\right)$;

3. Part related to the aggregate interlock contribution $\left(\mathrm{V}_{\mathrm{agg}}\right)$;

4. Part related to the contribution of the compression zone $\left(\mathrm{V}_{\text {comp }}\right)$.

The combination of these actions can be seen in Figure 7, and are described as follows:

$V_{c}=V_{\text {Res }}+V_{\text {agg }}+V_{\text {dowel }}+V_{\text {comp }}$

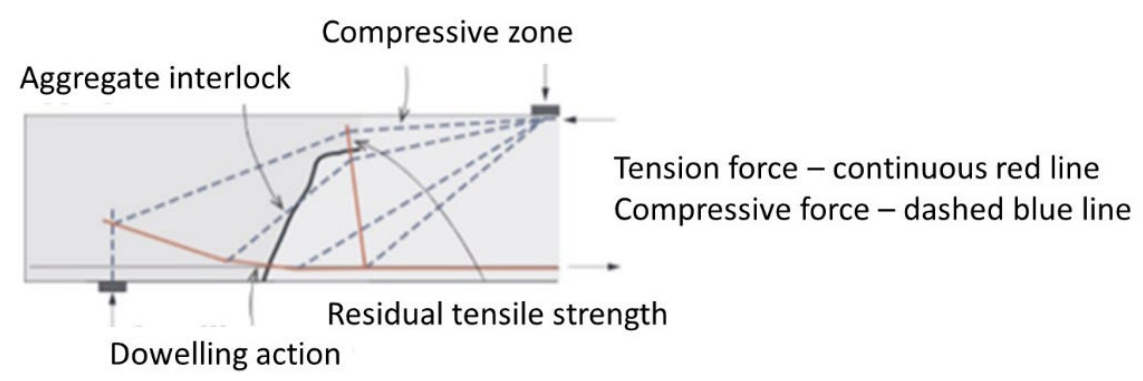

Figure 7. Basic shear transfer actions described with strut and tie models [11]. 
These four mechanisms are responsible for the transmission of a part of the total shear force along the element, as follows:

- $\mathrm{V}_{\text {comp }}$ corresponds to the shear force transferred through the compressive chord originated by the flexure.

- $\mathrm{V}_{\mathrm{Res}}$ corresponds to the residual tensile stresses due to "concrete bridges" along the crack. According to Marquesi [6], cracks with widths of up to $0.15 \mathrm{~mm}$ are capable of transmitting shear force through residual stresses.

- $\mathrm{V}_{\text {agr }}$ corresponds to the part of the shear force transmitted through the aggregate interlock. $\mathrm{V}_{\text {agr }}$ is transferred after the appearance of a flexural crack and retransmitted by the tensile stress in the element web. The existence of significant roughness between the aggregates contributes to prevent the sliding of the crack surfaces. This interlock allows the transmission of oblique forces across the cracks. In the case of concrete with compressive strength up to $70 \mathrm{MPa}$, cracks occur in the cementitious matrix. On the other hand, for concrete with a compressive strength greater than $70 \mathrm{MPa}$, the cracks pass through the aggregates, and, thus, the interlock action is lost.

- $\mathrm{V}_{\text {dowel }}$ corresponds to the part of the shear force transferred by means of dowel action. $\mathrm{V}_{\text {dowel }}$ is transmitted through the flexural crack by the longitudinal reinforcement, which behaves like a connecting pin between the crack surfaces, being retransmitted by tension in the web section between two adjacent cracks. In addition, the longitudinal reinforcement also helps to prevent further crack widths and contributes to the other transfer mechanisms previously mentioned.

According to Cavagnis et al. [11], shear strength and the strain capacity are related to a criterion of failure, and wherein lower strengths are associated with greater strain capacities (and thus, greater crack widths). Also, the contribution of each shear-transfer action depends on the location of the shear critical crack, its widths and spreading, and its roughness properties. In their studies, Cavagnis et al. [11] concluded that for slender slab members, the failure load is eventually governed by shear transfer actions so that:

$\checkmark$ For low crack widths, both aggregate interlock and residual tensile strength of concrete play an important role. For large crack widths, aggregate interlock becomes more dominant.

$\checkmark$ The dowel action of the longitudinal reinforcement exhibits a more limited contribution than the other shearcarrying actions. Yet, its contribution is not necessarily negligible.

$\checkmark$ The contribution of the inclined compression chord for slender members depends significantly on the location of the tip of the critical shear crack. For critical shear cracks located at a certain distance from the load introduction, its contribution is relatively low.

\subsubsection{Concrete tensile strength}

The concrete tensile strength contribution in the shear strength is taken into account by the Brazilian codes of practice [2], [4] by means of the term $0.25 \cdot f_{\text {ctd }}$, as shown in Figure 6 . The equation of $V_{\text {Rd1 }}$ (Figure 6) prescribed by Brazilian codes corresponds to a similar equation employed by the previous version of EC2 [12]. According to the EC2 Commentary [13], there was a change in the formula recommended by EC2 due to high values of standard deviations obtained in elements composed of high-strength concrete, above $50 \mathrm{MPa}$. However, this reality does not apply to slabs commonly used in Brazil, whose concrete usually has a strength around $50 \mathrm{MPa}$.

\subsubsection{Influence of the axial prestressing force in the shear strength}

Tension forces present in a structural element favor the appearance of cracks and contribute to the increasing of the existing cracks widths, reducing the shear strength. On the other hand, the compression forces are able to delay the appearance of cracks and to contribute to the "closing" of existing cracks, ensuring the transfer of efforts.

In the equations recommended by EC2 [12] and Brazilian codes, the influence of axial stress in shear strength is considered through the term $\left(0.15 \cdot \sigma_{\mathrm{cp}} \cdot \mathrm{b}_{\mathrm{w}} \cdot \mathrm{d}\right)$, positive for compression and negative for tension. This $\left(0.15 \cdot \sigma_{\mathrm{c}} \cdot \mathrm{b}_{\mathrm{w}} \cdot \mathrm{d}\right)$ originally comes from the prestressing contribution and is later extrapolated for the contribution of any axial effort in the shear strength.

\subsubsection{Transfer length}

The transfer length is defined as the bonded length between concrete and the tendon that is required to develop an effective prestressing force in both within the anchorage zone [14]. The transfer length is essential to the shear resistance 
design, even more in precast hollow core slabs that do not have shear reinforcement. However, it is exceedingly difficult to determinate this parameter due to its variability.

In the anchorage zone of pre-tensioned concrete elements (such as hollow core slabs), some extremely important parameters must be considered, as such:

- Transfer length of prestressing strands/wire $\left(l_{\mathrm{bpt}}\right)$ : necessary length to transfer the prestress tension from the strand/wire to the concrete.

- Regularization length $\left(l_{\mathrm{p}}\right)$ : necessary length to distribute the prestress tension through the concrete crosssection.

- Anchorage length $\left(l_{\mathrm{bpd}}\right)$ : necessary length to anchorage in the concrete all the tension in the strand/wire, in Ultimate Limit State.

The bond between concrete and reinforcement exists because of three different mechanisms: bond by adhesion, bond by friction, and mechanical bond

Bond by adhesion originates from the physicochemical bond between the concrete slurry and the reinforcement. This bond has a small resistance and is lost when small slips happen.

Bond by friction happens due to the surface roughness of all the components and the transverse compression of the reinforcement. This transverse compression happens because the reinforcement attempts to return to its initial diameter after the release of the prestress, being gradually prevented by the concrete surrounding it (without prevention in external cross-section and totally prevented after a certain length). Such a situation is called the Hoyer effect, but it is necessary to identify the hollow core slab's design situation.

The mechanical bond exists due to the reinforcement protrusions (strands or wires), causing the interlock between the rebars and the surrounding compressed concrete.

Through these three mechanisms, it is possible to understand that the bond stress between concrete and reinforcement. Assuming that this bond tension is constant, Eurocode 2 [12] presents a formulation to verify it, considering the type of reinforcement, the bond condition, and the tensile strength at the moment of the release of prestress. The name of this bond stress is $\mathrm{f}_{\mathrm{bpt}}$ and can be determined by Equation 2 .

$f_{b p t}=\eta_{p l} \cdot \eta_{1} \cdot f_{c t d}$

Where:

$\eta_{\mathrm{p} 1}$ : Coefficient that takes into account the type of tendon;

$\eta_{1}$ : Coefficient that takes into account the bond situation at release. It is 1 for good bond condition and 0.7 otherwise.

$f_{\text {ctd }}$ : is the design tensile value of strength at the time of release.

Considering this bond stress as constant, it can be assumed that the prestress will be transferred to the concrete through a determined transfer length $l_{\mathrm{bpt}}$. This length, assuming the Eurocode 2 [12] method, is calculated by Equation 3:

$$
l_{b p t}=\alpha_{1} \cdot \alpha_{2} \cdot \phi \cdot \frac{\sigma_{m p 0}}{f_{b p t}}
$$

Where:

$\alpha_{1}$ : Coefficient that takes into account the type of prestress release, using 1 for gradual release and 1.25 for sudden release.

$\alpha_{2}$ : Coefficient that takes into account the cross-section of the reinforcement, using 0.25 for circular cross-section and 0.19 for 3 and 7 -wire strands.

$\phi:$ is the nominal diameter of the tendon.

$\sigma_{\mathrm{mp} 0}$ : is the tendon stress just after the release.

As described, the transfer length must be modified accordingly to the verification made (tendon slippage, shear strength, spalling, among others). It occurs due to the change in the diameter of the tendon according to the existent stress, modifying the transverse compression stress (bond by friction). The Eurocode 2 [12] presents the possibilities of the transfer length using $1_{\mathrm{pt} 1}$ and $1_{\mathrm{pt}}$, (modifications of the $\mathrm{l}_{\mathrm{bpt}}$ ). These lengths are used accordingly to the necessary verification. Their values are: 
$l_{p t 1}=0.8 \cdot l_{b p t}$

$l_{p t 2}=1.2 \cdot l_{b p t}$

Thereby, the increase of stress in a tendon generates a bigger transfer length, so the study of a hollow core slab in the Ultimate Limit State considers the higher value $1_{\mathrm{pt} 2}$.

\subsection{Determination of flexure-shear strength}

At the beginning of the research on prestressed hollow core slabs in Brazil, related to the study of their shear capacity, the aim was to observe if the equation recommended by the NBR 6118 [4] would need adjustments to represent the behavior of hollow core slabs with shallow slabs, between 150 to $200 \mathrm{~mm}$ deep, which were the main heights produced in Brazil at that time.

The research carried out by Fernandes [15] helped to define the standard test to determine the flexure-shear capacity of prestressed hollow core slabs, which was not included in any Brazilian code until then, after a significant number of tests were performed inside of precast factories in Brazil. It helped to detail a test procedure based on the quality control manual of FIP [16].

In the research carried out by Catoia [17], 65 tests were assembled, varying the typology of the slabs (different depths, with or without a cast in place topping and filled core), to verify if the recommended equation in the code NBR 6118 [4] would be capable to represent the usual behavior of the slabs. Typical slabs produced in four different industries in Brazil were used. Moreover, the recommended equations of ACI [18] and EC2 [12] were verified too. From an extensive study, it was possible to observe that if considered a force applied in a distance equal to $2.5 \mathrm{~h}$ from the support axis, the results obtained at tests were more approximated to the results obtained using the equation of the code NBR 6118 [4] than for the values reached using the equations of ACI [18] and EC2 [12], accordingly to the Figure 8. It was found that the equation recommended by the EC2 [12] gives results more conservative than the values obtained in experiments, and the equation recommended by ACI [18] presents a better approximation when the force is applied more distant from the support axis of the slab (near to 5.75h). In her research, Catoia [17] contributed to a better knowledge of the structural behavior of most used hollow core slabs produced in Brazil, in particular, slabs with 150 and $200 \mathrm{~mm}$ in height, providing a safe indication that the equation for shear capacity prescribed by the Brazilian code of practice for structural concrete NBR 6118 [4] could be adopted to design of the shear strength of hollow core slabs by the new code NBR 14861 [2], which was still being developed at that time. After that, new researches in Brazil started to focus on the structural performance of slabs with higher depths, wherein it is possible to develop the tension shear mechanism of the slab web, in a region without bending cracks, achieving higher shear capacities but with a brittle manner of failure.

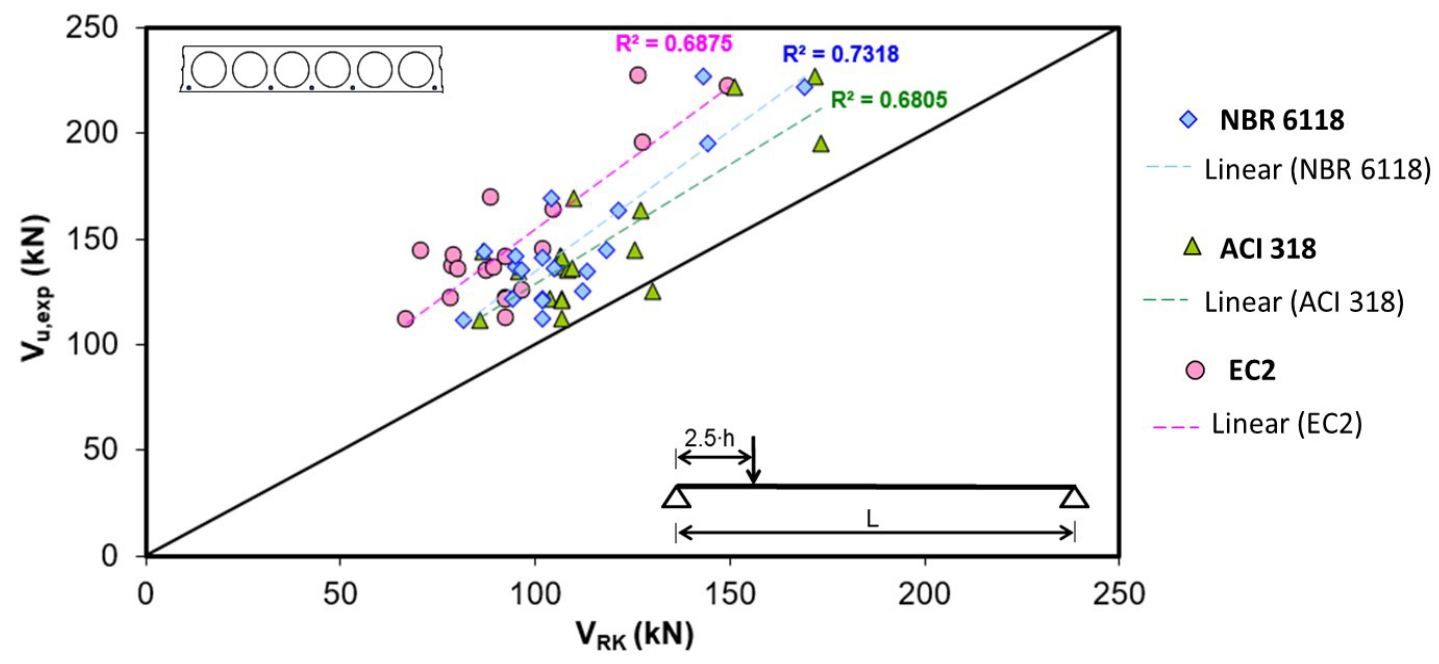

Figure 8. Relationship between $V_{u, e x p}$ e $V_{R k}$ considering the use of equations recommended by NBR 6118, EC2 e ACI 318 [17]. 


\subsubsection{Origin of the coefficient 0.15}

The design models used to determine the shear strength of prestressed hollow core slabs come from experiments considering a rectangular beam section. The contribution parcel of the prestress $\left(\mathrm{V}_{\mathrm{p}}\right)$ can be obtained by an analytical deduction, as shown by Marquesi [6]. Basically, the influence of prestress can be considered based on the principle proposed by Hedman and Losberg [19] that considered the rectangular beam cross-section and propose that in relation to the shear strength, a prestressed beam can be considered as just reinforced beam when the decompression flexure moment is reached. In this context, the shear strength of a prestressed concrete element is the sum of the shear strength of the reinforced concrete and the parcel of the shear force generated by the load responsible for provoking the decompression in cross-section studied, being formulated as:

$V_{R d}=V_{c}+V_{p}$

Thus:

$\mathrm{V}_{\mathrm{c}}$ : shear strength of a reinforced concrete beam;

$\mathrm{V}_{\mathrm{p}}$ : contribution of the prestress force in the shear strength, being formulated as:

$V_{p}=\frac{M_{0}}{a}$

Where:

$\mathrm{M}_{0}$ : decompression flexure moment;

a: distance of the force to the support axis (Figure 9).

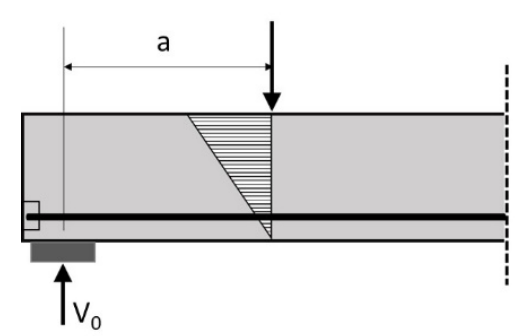

Figure 9. Calculation of the prestress contribution in the shear strength. [adapted from 19].

Thus, the calculus of $\mathrm{V}_{\mathrm{p}}$ considers $\mathrm{M}_{0} / \mathrm{a}$, and the moment $\mathrm{M}_{\mathrm{o}}$ is determined by assuming the equilibrium of stresses in the bottom fiber of a prestressed beam, using the equation:

$\frac{N_{p} \cdot e_{p}}{W}+\frac{N_{p}}{A}-\frac{M_{0}}{W}=0$

Being:

$W=\frac{I}{y}=\frac{\frac{b \cdot h^{3}}{12}}{\frac{h}{2}}=\frac{b \cdot h^{2}}{6}$

And isolating $\mathrm{M}_{0}$ : 
$M_{0}=N_{p} \cdot e_{p}+\frac{N_{p}}{A} \cdot \frac{b \cdot h^{2}}{6}$

\section{Considering}

$V_{p}=\frac{M_{0}}{a}$

Replacing Mo, then:

$V_{p}=\left(N_{p} \cdot e_{p}+\frac{N_{p}}{b \cdot h} \cdot \frac{b \cdot h^{2}}{6}\right) \cdot \frac{1}{a} \quad \rightarrow \quad V_{p}=\left(N_{p} \cdot e_{p}+\frac{N_{p} \cdot h}{6}\right) \cdot \frac{1}{a}$

Putting $\mathrm{N}_{\mathrm{p}}$ and $\mathrm{h}$ in evidence:

$V_{p}=N_{p} \cdot\left(\frac{h}{a}\right) \cdot\left(\frac{e_{p}}{h}+\frac{l}{6}\right)$

Considering the effective depth of a cross section as $\mathrm{d}=0.85 \cdot \mathrm{h}[13], \mathrm{h}=1.176 \cdot \mathrm{d}$ and then:

$V_{p}=1.18 \cdot N_{p} \cdot \frac{d}{a} \cdot\left(\frac{e_{p}}{h}+\frac{1}{6}\right)$

Assuming $\mathrm{e}_{\mathrm{p}} / \mathrm{h}=0.35$ (according to [13], in most shears experiments made by Hedman and Losberg [19] in beams, the relation $\mathrm{e}_{\mathrm{p}} / \mathrm{h}$ correspond to 0.35$)$, then:

$V_{p}=1.18 \cdot N_{p} \cdot \frac{d}{a} \cdot(0.35+0.166) \rightarrow V_{p}=0.608 \cdot \frac{N_{p}}{\frac{a}{d}}$

With the distance of the force to the support axis (a) varying from $2.5 \cdot \mathrm{d}$ to $4.0 \cdot \mathrm{d}$, it has:

Superior limit (minimum distance $\mathrm{a}=2.5 \cdot \mathrm{d})$ :

$V_{p}=0.608 \cdot \frac{N_{p}}{\frac{2.5 \cdot d}{d}}=0.24 \cdot N_{p} \quad \rightarrow \quad V_{p}=0.24 \cdot \sigma_{p} \cdot b \cdot d$

Inferior limit (maximum distance $\mathrm{a}=4.0 \cdot \mathrm{d})$ :

$V_{p}=0.608 \cdot \frac{N_{p}}{\frac{4 \cdot d}{d}}=0.15 \cdot N_{p} \quad \rightarrow \quad V_{p}=0.15 \cdot \sigma_{p} \cdot b \cdot d$

Therefore, varying the relation a/d between $2.5 \cdot \mathrm{d}$ and $4 \cdot \mathrm{d}$, as it happens in most of shear tests, the parcel of the contribution of the acting prestressing forcers $V_{p}$ in the shear strength $V_{R d 1}$ will vary from $0.15 \cdot \sigma_{p} \cdot b \cdot d$ to $0.24 \cdot \sigma_{p} \cdot b \cdot d$. In such way, the factor 0.15 corresponds to the lower limit. 


\subsubsection{Recommendations based on NBR 14861:2011 and NBR6118:2114}

According to item 19.4.1 of the code NBR 6118 [4], solid or ribbed slabs can be executed without transversal reinforcement to resist the tensile force from the shear mechanism when they meet the requirement:

$V_{S d} \leq V_{R d 1}$

Where:

$V_{R d 1}=\left[\tau_{R d} \cdot k \cdot\left(1.2+40 \cdot \rho_{1}\right)+0.15 \cdot \sigma_{c p}\right] \cdot b_{w} \cdot d$

$\tau_{R d}=0.25 \cdot f_{c t d}$

$f_{c t d}=\frac{f_{c t k, i n f}}{\gamma_{c}}$

$\rho_{l}=\frac{A_{s l}}{\left(b_{w} \cdot d\right)}$

$\sigma_{c p, I}=\left(\frac{N_{s d}}{A_{c}}\right) \cdot \alpha$

$k=1.6-d \geq 1$, with $\mathrm{d}$ in meters $(\mathrm{m})$

Where:

$\tau_{\mathrm{Rd}}$ design concrete shear strength

$\mathrm{f}_{\text {ctd }}$ is the design concrete tensile strength at the web the hollow core slab

$b_{w}$ : minimum width of the cross-section in the effective depth $d$;

$\mathrm{A}_{\mathrm{s} 1}$ : tensile reinforcement cross-section area;

$\rho_{1}$ : reinforcement ratio for longitudinal reinforcement only in the hollow core slabs cross-section area;

$\sigma_{\mathrm{cp}}$ : compression stress due to design prestress force for slabs without filled cores (or with cores filled after the release);

$\mathrm{N}_{\mathrm{sd}}$ : longitudinal force in the section due to prestress or load (consider positive signal to compression)

$\mathrm{A}_{\mathrm{c}}$ : hollow core slab cross-section area.

Furthermore, in the same item of the referred code, it is also stated that for pre-tensioning it must have an additional reduction in the term $\mathrm{V}_{\mathrm{p}}$ in order to consider the effect of the transfer length on the effective prestressing force in order to determine the slab bearing capacity. Thus, the coefficient 0.15 that multiplies the compression stress $\sigma_{\mathrm{cp}}$ due to design prestress force needs to be also multiplied by an additional reduction factor. During the process of the preparation of the final text of NBR 14861 [2] a reduction factor called $\alpha$ was incorporated within the calculation of the compression stress $\sigma_{\mathrm{cp}}$ with the purpose to take into account the effect of the reduction the prestressing in the prestressing transfer length and thus harmonizing both texts of NBR 14861 and NBR 6118. According to NBR 14861 [2]:

$\alpha=\frac{l_{x}}{l_{p t 2}} \quad \leq 1$

Where: $1_{\mathrm{x}}$ : distance of the section $\mathrm{x}$ to the end of the slab; $1_{\mathrm{pt} 2}$ : upper design value for the transfer length (fixed in $85 \cdot \mathrm{f}$ according to the FIB Bulletin 6 [3]). 
However, there was an additional reduction factor $\alpha$ required in order to guarantee the safety of the flexure-shear mechanism of a prestressed concrete slab with or without structural toppings according to the FIB Bulletin 6 [3], also inspired in the CEB-FIP MC1978 [5].

\section{TESTS TO DETERMINE THE SHEAR CAPACITY OF PRESTRESSED HOLLOW CORE SLABS}

As aforesaid, the shear strength of hollow core slabs depends on several factors, such as: concrete tensile strength, geometric shapes of the cores, concrete dosage, and the fabrication process. The concrete tensile strength is difficult to be determined considering the standard methods and the influence of the cross-section shape and of the fabrication method can not be directly determined.

Thus, it was developed a pattern test to determine the shear capacity of hollow core slabs, with the purpose to verify the operation of the extrusion as well as to determine some parameters related to bearing capacity. This pattern test initially was indicated by FIP [16] and by European Code EN 1168 [20], being posteriorly added in NBR 14861 [2].

\subsection{Characterization of the hollow core slabs}

It is important to emphasize that the present study is restricted to the prestressed hollow core slabs with a crosssection composed by circular voids and a maximum height of $210 \mathrm{~mm}$.

In addition, all slabs presented flexure shear failure. The description of the tested slabs can be observed in Table 1.

Table 1 Characterization of the tested slabs.

\begin{tabular}{|c|c|c|c|c|c|c|c|c|}
\hline Identification & $\begin{array}{c}\mathbf{n}^{\circ} \\
\text { bars }\end{array}$ & $\begin{array}{c}P_{i} \\
(k N) \\
\end{array}$ & $\begin{array}{l}N_{p, 00} \\
(k N) \\
\end{array}$ & $\begin{array}{c}\mathbf{A}_{\mathbf{c}} \\
\left(\mathbf{m m}^{2}\right) \\
\end{array}$ & $\begin{array}{c}\mathbf{f}_{\text {ck }} \\
\text { (MPa) } \\
\end{array}$ & $\begin{array}{c}\mathbf{f}_{\text {ctk,inf }} \\
\text { (MPa) } \\
\end{array}$ & $\begin{array}{c}\Sigma \mathbf{b}_{\mathrm{w}} \\
(\mathbf{m m})\end{array}$ & $\begin{array}{c}\mathrm{d} \\
(\mathrm{mm})\end{array}$ \\
\hline L1-15-6D9.5-X & 6 & 79 & 379.2 & 131236 & 55.9 & 3.072 & 463.5 & 115.2 \\
\hline L2-20-8D12.7-X & 8 & 144.5 & 924.8 & 170503 & 48.4 & 2.789 & 411.5 & 167.1 \\
\hline L3-20-6D12.7-Y & 6 & 145 & 696.0 & 135685 & 53.3 & 2.973 & 250.2 & 169.5 \\
\hline L4-20-6D12.7-Y & 6 & 145 & 696.0 & 132400 & 53.5 & 2.980 & 269.3 & 174.8 \\
\hline L5-20-6D12.7-Y & 6 & 145 & 696.0 & 132610 & 53.5 & 2.980 & 269.0 & 168.4 \\
\hline L6-20-7D9.5-Y & 7 & 75 & 420.0 & 130553 & 53.5 & 2.983 & 262.4 & 165.6 \\
\hline L7-20-7D9.5-Y & 7 & 75 & 420.0 & 136572 & 53.5 & 2.983 & 268.7 & 164.7 \\
\hline L8-20-7D9.5-Y & 7 & 75 & 420.0 & 134024 & 53.5 & 2.983 & 263.9 & 167.5 \\
\hline L9-20-7D9.5-Y & 7 & 75 & 420.0 & 135666 & 53.5 & 2.983 & 267.9 & 169.2 \\
\hline L12-20-5D12.7-Z & 5 & 114 & 456.0 & 137795 & 40.0 & 2.456 & 320.0 & 165.0 \\
\hline L13-20-5D12.7-Z & 5 & 114 & 456.0 & 137795 & 40.0 & 2.456 & 320.0 & 165.0 \\
\hline L14-20-5D12.7-Z & 5 & 114 & 456.0 & 137795 & 40.0 & 2.456 & 320.0 & 165.0 \\
\hline L15-20-5D12.7-Z & 5 & 114 & 456.0 & 137795 & 40.0 & 2.456 & 320.0 & 165.0 \\
\hline L17-21-7D9.5-W & 7 & 81.03 & 453.8 & 146064 & 47.0 & 2.735 & 312.5 & 171.4 \\
\hline L18-21-7D9.5-W & 7 & 81.03 & 453.8 & 145948 & 47.0 & 2.735 & 307.0 & 172.9 \\
\hline L25-16-5D9.5-W & 5 & 81.03 & 324.1 & 126449 & 47.0 & 2.735 & 323.5 & 134.6 \\
\hline L26-16-5D9.5-W & 5 & 81.03 & 324.1 & 129085 & 47.0 & 2.735 & 346.5 & 135.7 \\
\hline
\end{tabular}

Considered: Total losses of $20 \% ; \mathrm{A}_{\mathrm{s}, 9.5 \mathrm{~mm}}=55.5 \mathrm{~mm}^{2}, \mathrm{~A}_{\mathrm{s}, 12.7 \mathrm{~mm}}=101 \mathrm{~mm}^{2}$.

\subsection{Methodology}

To analyze the prestress contribution in the flexure-shear capacity, it was considered an effective reduction factor (called $\alpha_{\mathrm{ef}}$ ) which value was experimentally determined for each tested slab.

\subsubsection{Shear tests}

From several experimental studies and tests carried out by the Research Group for Studies and Technology in Precast Concrete (NETPre) that have been carried out at UFSCar since 2007, it was later systematized a standard procedure for quality control tests of hollow core slabs, which were adapted from the test recommendations from FIP [16] and EN 1168 [20]. The test setup is illustrated in Figure 10 and described as follows. 


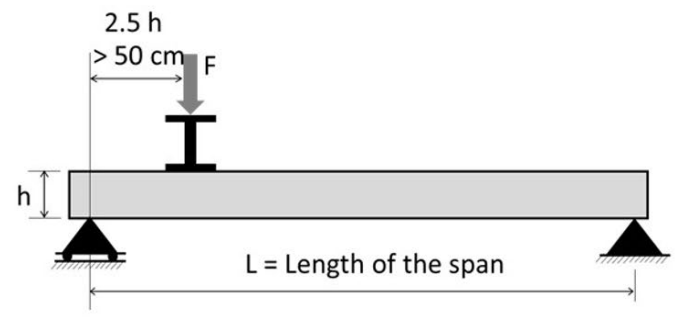

a)

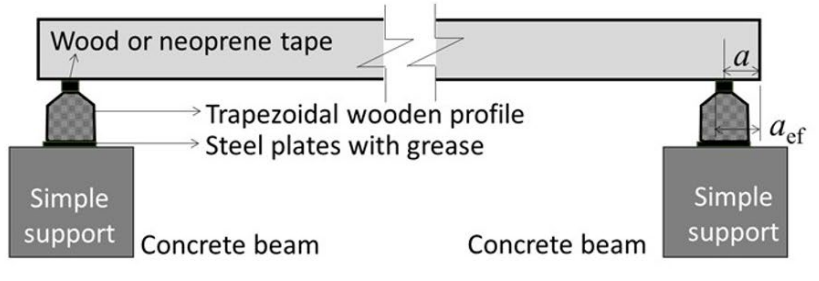

b)

Figure 10. a) Layout of the pattern test to determine the shear capacity of hollow core slabs; b) Detail of the support.

Elements with a length of $6 \mathrm{~m}$ and actual width were tested under temperatures between $0^{\circ} \mathrm{C}$ and $40^{\circ} \mathrm{C}$. With the purpose of obtaining reference values of concrete strength, cylindrical specimens were tested. These specimens were fabricated with the same conditions employed in the slabs tested, including the same concrete.

In order to obtain an unfavorable effect of flexure on the shear strength mechanism, the load was applied at a distance of $2.5 \mathrm{~h}$ (where $\mathrm{h}$ is the slab height) from the support, being this distance always greater than $50 \mathrm{~cm}$. The transfer of force to the slab was performed by a rigid steel beam (Figure 10a), with a height of $250 \mathrm{~mm}$. A uniform distribution of forces was ensured over the entire width. Below the steel transfer beam, sand was used to compensate possible irregularities present on the slab surface that prevent its proper leveling.

The supports were composed of a trapezoidal wooden profile positioned on a concrete beam, according to Figure 10b). To guarantee proper transfer of shear force over the support, it was used a wood with a thickness of $10 \mathrm{~mm}$ (instead of wood, a neoprene tape could be used). At the end of the slab, next to the force application was created a roller support with the purpose to avoid the appearance of horizontal efforts. The roller support was obtained with the use of grease between two thin steel plates placed between the trapezoidal wooden profile and concrete beam, as shown in Figure 10b).

Hydraulic actuators with a loading capacity of $500 \mathrm{kN}$ were used for continuous application of load (monotonic test) with a speed of around $50 \mathrm{kN} / \mathrm{min}$. The load was applied on the unidirectional roller support located over the transfer steel beam. Load cell (CC) with a capacity of $1000 \mathrm{kN}$ were used to measure the applied force, and linear displacement transducers (TD) were used to measure vertical displacements next to the point of the force application. The experimental tests used in this paper were carried out in the [15] and [17].

It is noteworthy that these correspond to control tests because they simulate a critical design situation, where a concentrated load is applied in a region with the risk of cracking in thin slabs (up to $21 \mathrm{~cm}$ ).

Figure 11 illustrates the cracking configuration of the slabs L2 and L4 close to the failure. In both slabs, it is possible to observe the interaction of shear and flexure mechanisms.
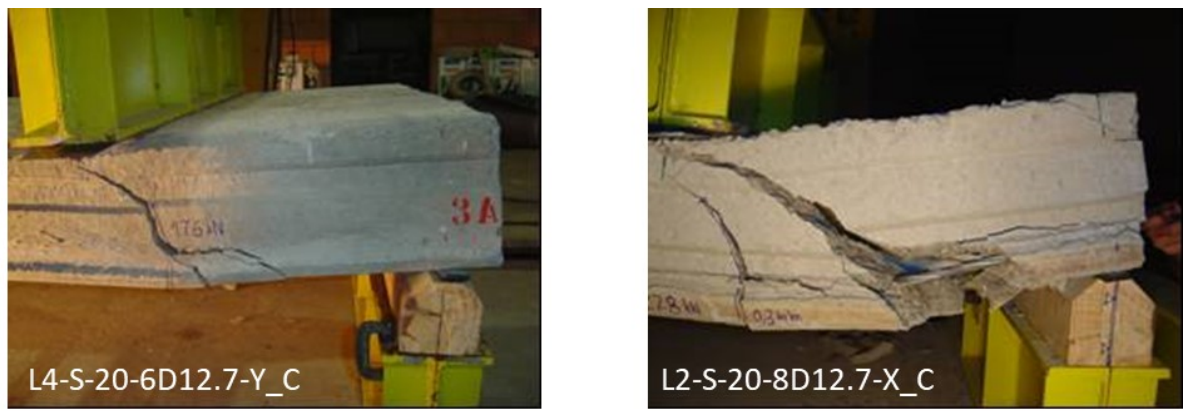

Figure 11. Hollow core slabs submitted to the shear test [17]. 


\subsubsection{Determination of $\alpha_{\mathrm{ef}}$}

According to NBR 14861 [2], it is possible to divide the equation to determine the shear strength of prestressed hollow core slabs into two parcels, one that considers the concrete contribution $\left(\mathrm{V}_{\mathrm{c}, 1}\right)$ and the other that consider the tendons contribution $\left(\mathrm{V}_{\mathrm{p}, 1}\right)$, as follows.

$V_{R d l}=V_{c, l}+V_{p, l}$

From the experimental tests, it is possible to determine the shear strength $V_{R u \text { exp }}$, which can be described by the following equation.

$$
V_{R u, e x p}=V_{c, k}+V_{p, k}
$$

In this case, $\mathrm{V}_{\mathrm{c}, \mathrm{k}}$, and $\mathrm{V}_{\mathrm{p}, \mathrm{k}}$ corresponds to the characteristic values (without considering any safety factor) of the tendons and concrete contribution, respectively.

Isolating the part related to the tendon's contribution $\mathrm{V}_{\mathrm{p}, \mathrm{k}}$ :

$V_{p, k}=V_{R u, \exp }-V_{c, k}$

Replacing the equation of $\mathrm{V}_{\mathrm{p}, \mathrm{k}}$ as a function of the reduction factor $\alpha_{\mathrm{ef}}$, it is possible to obtain the following equation:

$$
V_{p, k}=\alpha_{e f} \cdot \sigma_{c p} \cdot b_{w} \cdot d=V_{R u, e x p}-V_{c, k}
$$

Thus, isolating the reduction factor $\alpha_{\mathrm{ef}}$, it is possible to determine its value from the results of shear strength obtained in the tests, as follows:

$\alpha_{e f}=\frac{V_{R u, e x p}-V_{c, k}}{\sigma_{c p} \cdot b_{w} \cdot d}$

Where:

$V_{c, k}=0.25 \cdot f_{c t k, i n f} \cdot k \cdot\left(1.2+40 \cdot \rho_{I}\right) \cdot \Sigma b_{w} \cdot d ; f_{c t k, i n f}=0.7 \cdot 0.3 \cdot\left(f_{c k}\right)^{\frac{2}{3}}$

$\sigma_{c p}=\frac{N_{p}}{A_{c}}$

\section{RESULTS AND DISCUSSIONS}

From the experimental results of the shear strength $\left(\mathrm{V}_{\mathrm{Ru}, \mathrm{exp}}\right)$, the values for the contribution of the concrete strength $\left(\mathrm{V}_{\mathrm{c}, \mathrm{k}}\right)$ and the values of $\alpha_{\mathrm{ef}}$ were calculated, which are shown in Table 2. Considering the slabs tested, it has been found an average value of $\alpha_{\mathrm{ef}, \text { average }}=0.37$, with values of $\alpha_{\mathrm{ef}}$ ranging from 0.21 to 0.65 . In addition, it is possible to observe that the slabs with the presence of tendons with $12.7 \mathrm{~mm}$ diameter presented lower values of $\alpha_{\mathrm{ef}}$ than the slabs with tendons of $9.5 \mathrm{~mm}$ diameter (as can be seen in Figure 12). This can be explained due to the fact that slabs with tendons of smaller diameters need shorter lengths for the transfer of prestressing to concrete, which results in lower values of $l_{\text {bpt. }}$ This means that the smaller area of concrete will not have the prestressing fully distributed, and, consequently, the contribution of prestressing in the slab shear strength will be greater. Thus, the factor $\alpha_{\mathrm{ef}}$ that decreases the contribution of prestressing in the shear strength will present higher values. It is noteworthy that the importance of the transfer length 
is related to the fact that in cases where the failure of slab occurs due to flexure-shear model, the maximum tensile stress will occur in a place with the greatest interaction between the bending moment and shear stress, that is between $2.5 \cdot \mathrm{d}$ and $4 \cdot \mathrm{d}$. It is important to highlight that the strength parcel related to the prestressing also depends on the slab bearing length over the support. The support region provides compression stresses that contribute to the anchorage of the prestress bars, and consequently, with the transfer of the compression stress to the precast concrete element.

Table 2 Determination of the total reduction factor $\alpha_{\mathrm{ef}}$

\begin{tabular}{|c|c|c|c|c|c|c|c|}
\hline Identification & $\frac{k}{(1.6-d)}$ & $\rho$ & $\begin{array}{c}\sigma_{\mathrm{ci}} \\
(\mathrm{MPa})\end{array}$ & $\frac{\sigma_{c p}}{(\mathrm{MPa})}$ & $\begin{array}{c}V_{\mathbf{c}, \mathbf{k}} \\
(\mathbf{k N})\end{array}$ & $\begin{array}{c}V_{\text {Ru,exp }} \\
(\mathrm{kN})\end{array}$ & $\boldsymbol{\alpha}_{\mathrm{ef}}$ \\
\hline L1-S-15-6D9.5-X_C & 1.485 & 0.0062 & 1.4 & 2.9 & 88.2 & 134.5 & 0.30 \\
\hline L2-S-20-8D12.7-X_C & 1.433 & 0.0118 & 1.4 & 5.4 & 114.7 & 222.4 & 0.29 \\
\hline L3-S-20-6D12.7-Y_C & 1.431 & 0.0143 & 1.4 & 5.1 & 79.9 & 125.1 & 0.21 \\
\hline L4-S-20-6D12.7-Y_C & 1.425 & 0.0129 & 1.4 & 5.3 & 85.7 & 163.5 & 0.31 \\
\hline L5-S-20-6D12.7-Y_C & 1.432 & 0.0134 & 1.4 & 5.2 & 83.8 & 144.5 & 0.26 \\
\hline L6-S-20-7D9.5-Y C & 1.434 & 0.0089 & 1.4 & 3.2 & 72.4 & 121.7 & 0.35 \\
\hline L7-S-20-7D9.5-Y_C & 1.435 & 0.0088 & 1.4 & 3.1 & 73.5 & 137.0 & 0.47 \\
\hline L8-S-20-7D9.5-Y_C & 1.433 & 0.0088 & 1.4 & 3.1 & 73.3 & 142.2 & 0.50 \\
\hline L9-S-20-7D9.5-Y_C & 1.431 & 0.0086 & 1.4 & 3.1 & 74.6 & 135.4 & 0.43 \\
\hline L12-S-20-5D12.7-Z_C & 1.435 & 0.0096 & 1.1 & 3.3 & 73.6 & 121.4 & 0.27 \\
\hline L13-S-20-5D12.7-Z_C & 1.435 & 0.0096 & 1.1 & 3.3 & 73.6 & 120.8 & 0.27 \\
\hline L14-S-20-5D12.7-Z_C & 1.435 & 0.0096 & 1.1 & 3.3 & 73.6 & 141.2 & 0.39 \\
\hline L15-S-20-5D12.7-Z_C & 1.435 & 0.0096 & 1.1 & 3.3 & 73.6 & 111.9 & 0.22 \\
\hline L17-S-21-7D9.5-W_C & 1.429 & 0.0073 & 1.5 & 3.1 & 78.0 & 136.2 & 0.35 \\
\hline L18-S-21-7D9.5-W_C & 1.427 & 0.0073 & 1.5 & 3.1 & 77.3 & 168.8 & 0.55 \\
\hline L25-S-16-5D9.5-W_C & 1.465 & 0.0064 & 1.5 & 2.6 & 63.5 & 111.1 & 0.43 \\
\hline L26-S-16-5D9.5-W_C & 1.464 & 0.0059 & 1.5 & 2.5 & 67.6 & 144.1 & 0.65 \\
\hline Average & & & & & & & 0.37 \\
\hline
\end{tabular}

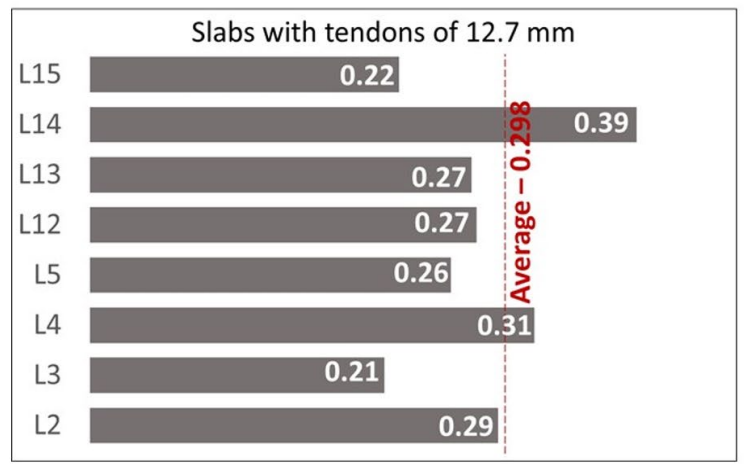

a)

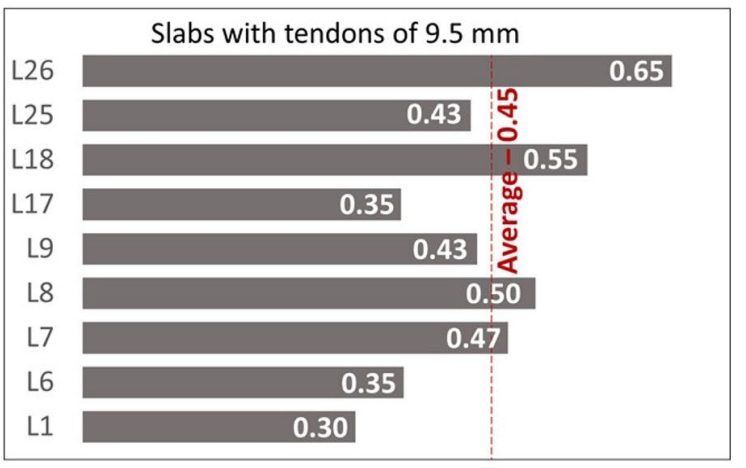

b)

Figure 12. a) Values of $\alpha_{\mathrm{ef}}$ considering slabs with tendons of $12.7 \mathrm{~mm}$; b) Values of $\alpha_{\mathrm{ef}}$ considering slabs with tendons of $9.5 \mathrm{~mm}$.

The study was carried out to calibrate the equation considering the strength value $V_{R k}$ using $\alpha_{\text {ef }}$ of 0.24 (named $V_{R k}$ (0.24) ) and of 0.15 (named $V_{R k}(0.15)$ ). The relationships between the experimental shear strengths and the characteristic shear strengths can be seen in Figure 13a).

It is possible to observe that most of the experimental results were higher than the characteristic values calculated considering the reduction factors of 0.24 and 0.15 . Therefore, the use of the coefficient 0.15 is shown to be a lower limit for the flexure-shear mechanism.

Moreover, the value of the design shear strength $\left(\mathrm{V}_{\mathrm{Rd}}\right)$, considering $\gamma_{\mathrm{c}}$ of 1.3 for the calculation of $\mathrm{V}_{\mathrm{cd}}$ and considering 0.15 for the calculation of $\mathrm{V}_{\mathrm{p}}$, was determined and compared with the ultimate experimental strength, as presented in Table 3 and Figure 13b). 
Table 3 Relationship between ultimate experimental shear strength $\left(\mathrm{V}_{\mathrm{Ru}, \mathrm{exp}}\right)$ and design shear strength considering $\alpha_{\mathrm{ef}}$ of 0.15 (VRd (0.15))

\begin{tabular}{|c|c|c|c|c|c|}
\hline Identification & $\begin{array}{c}V_{\text {Ru,exp }} \\
(\mathbf{k N}) \\
\end{array}$ & $\begin{array}{c}\text { V Rk (0.15) } \\
(\mathrm{kN})\end{array}$ & $\begin{array}{c}V_{\text {Rd (0.15) }} \\
(\mathbf{k N})\end{array}$ & 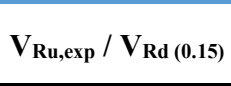 & $V_{R u, \exp } / V_{S d}$ \\
\hline L1-S-15-6D9.5-X_C & 134.5 & 111.4 & 91.0 & 1.48 & 2.07 \\
\hline L2-S-20-8D12.7-X_C & 222.4 & 170.7 & 144.2 & 1.54 & 2.16 \\
\hline L3-S-20-6D12.7-Y_C & 125.1 & 112.5 & 94.1 & 1.33 & 1.86 \\
\hline L4-S-20-6D12.7-Y_C & 163.5 & 122.8 & 103.0 & 1.59 & 2.23 \\
\hline L5-S-20-6D12.7-Y_C & 144.5 & 119.5 & 100.1 & 1.44 & 2.02 \\
\hline L6-S-20-7D9.5-Y_C & 121.7 & 93.4 & 76.6 & 1.59 & 2.23 \\
\hline L7-S-20-7D9.5-Y_C & 137.0 & 93.9 & 76.9 & 1.78 & 2.49 \\
\hline L8-S-20-7D9.5-Y_C & 142.2 & 94.0 & 77.1 & 1.84 & 2.57 \\
\hline L9-S-20-7D9.5-Y_C & 135.4 & 95.7 & 78.5 & 1.73 & 2.42 \\
\hline L12-S-20-5D12.7-Z_C & 121.4 & 99.8 & 82.8 & 1.47 & 2.06 \\
\hline L13-S-20-5D12.7-Z_C & 120.8 & 99.8 & 82.8 & 1.46 & 2.04 \\
\hline L14-S-20-5D12.7-Z_C & 141.2 & 99.8 & 82.8 & 1.70 & 2.38 \\
\hline L15-S-20-5D12.7-Z_C & 111.9 & 99.8 & 82.8 & 1.35 & 1.89 \\
\hline L17-S-21-7D9.5-W_C & 136.2 & 102.9 & 84.9 & 1.60 & 2.24 \\
\hline L18-S-21-7D9.5-W_C & 168.8 & 102.1 & 84.2 & 2.00 & 2.80 \\
\hline L25-S-16-5D9.5-W_C & 111.1 & 80.2 & 65.6 & 1.69 & 2.37 \\
\hline L26-S-16-5D9.5-W_C & 144.1 & 85.3 & 69.7 & 2.07 & 2.90 \\
\hline Average & & & & 1.63 & 2.28 \\
\hline
\end{tabular}

Thus, it was possible to determine an average value of the relationships between experimental values and design values equal to 1.63 . In other words, in the average, the experimental values were $63 \%$ higher than the theoretically calculated values. In addition, from Table 3, considering the relation $V_{\mathrm{Ru} \text {,exp }} / \mathrm{V}_{\mathrm{Sd}}$, for the coefficient $\gamma_{\mathrm{f}}$ of 1.4 , an average value for the safety factor was found higher than 2.28 .

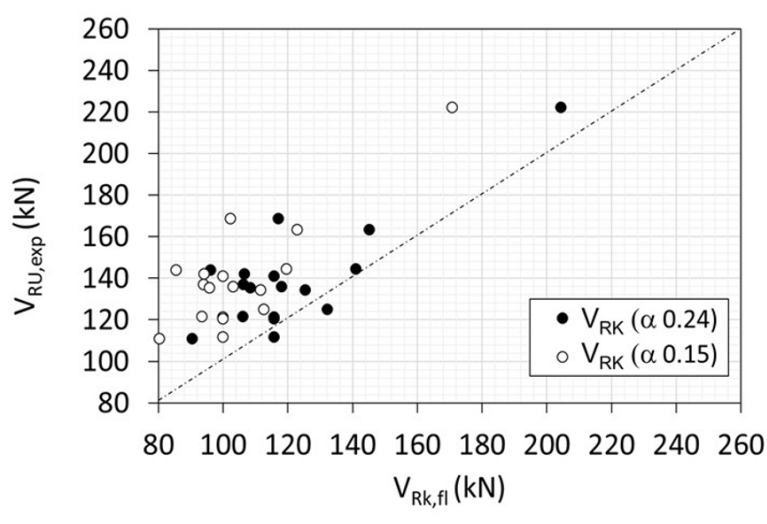

a)

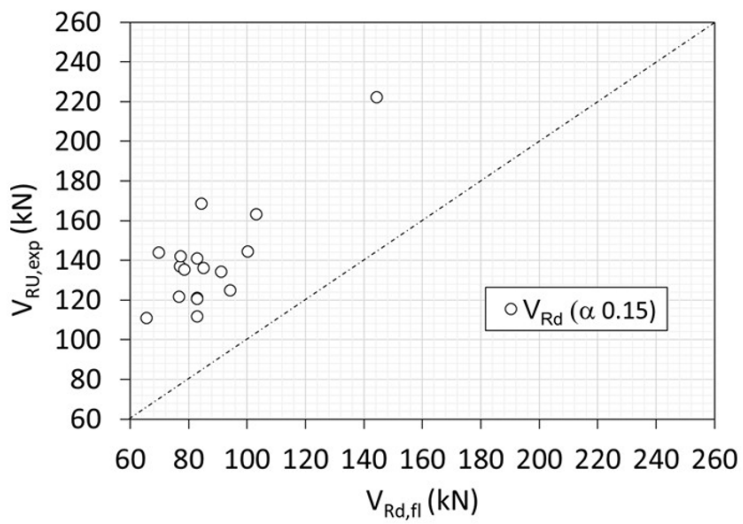

b)

Figure 13. a) Graphs $V_{R, \exp }$ versus $V_{R k}(0.24)$.and $V_{R, \exp }$ versus $V_{R k}(0.15)$, b) Graphs $V_{R u, e x p}$ versus $V_{R d}(0.15)$.

\section{CONCLUSIONS}

Hollow core slabs are prestressed precast elements without transverse reinforcement in which the bearing capacity is related to the shear mechanism of failure that is dependent on both the concrete section of the webs and the actual prestressing forces acting on the tendons at the critical section within the transfer length between a distance from $\mathrm{h}$ to $2 \mathrm{~h}$ from the support. For the slabs from 150 to $200 \mathrm{~mm}$ deep underline loads from $2 \mathrm{~h}$ to $4 \mathrm{~h}$ from the support, the shear capacity is mostly related to the flexure-shear mechanism, wherein there is a combination of bending and shear cracks. 
This paper has presented a literature review on the development of the main assumptions for the flexure-shear mechanism, which is the basis for the theoretical expression for the bearing capacity of hollow core slabs with and without structural topping according to NBR 14861 [2], which also was inspired by FIB Bulletin 6 [3].

Considering the characteristic tensile strength of concrete $\mathrm{f}_{\text {ctk, inf }}=0.7 \mathrm{f}_{\mathrm{ctm}}$ for the calculation of the term $\mathrm{V}_{\mathrm{c}, \mathrm{k}}=0.25 \cdot \mathrm{f}_{\mathrm{ckt}, \text { inf }} \cdot \mathrm{k} \cdot\left(1.2+40 \rho_{1}\right) \cdot \Sigma \mathrm{b}_{\mathrm{w}} \cdot \mathrm{d}$ and comparing the theoretically predicted values with the experimental results from shear tests of slabs with 150 and $200 \mathrm{~mm}$, it has been found an average value of $\alpha_{\mathrm{ef}, \text { med }}=0.37$ (being $\alpha_{\mathrm{ef}, \mathrm{med}}=0,298$ considering slabs with tendons of $\phi 12.7 \mathrm{~mm}$ and $\alpha_{\mathrm{ef} \text {,med }}=0,45$ considering slabs with tendons $\phi 9.5 \mathrm{~mm}$ ), with $\alpha_{\mathrm{ef}}$ ranging from 0.21 to 0.65 . Therefore, the $\mathrm{V}_{\mathrm{p}, 1}=0.15 \cdot \sigma_{\mathrm{cp}} \cdot \mathrm{b}_{\mathrm{w}} \cdot \mathrm{d}$ proved to be a lower limit to take into account the effective contribution of the prestressing tendons at the critical section in the transfer region, within a distance between $\mathrm{h}$ and $2 \mathrm{~h}$ from the support. Therefore, it has been verified that there is no further need for the reduction factor $\alpha=\mathrm{L}_{\mathrm{x}} / \mathrm{L}_{\mathrm{pt} 2}$ to be multiplied by the portion $0.15 \cdot \sigma_{\mathrm{cp}}$.

\section{ACKNOWLEDGEMENTS}

The authors acknowledge UFSCar and NETPre for providing laboratory facilities, CNPq for a PhD Scholarship, and $\mathrm{ABCIC}$ for the Institutional Support for the donation of hollow core slabs from different precast companies.

\section{REFERENCES}

[1] G. Lindström, Cross Section Design. Lausanne: CEB-FIB, 2007. Draft.

[2] Associação Brasileira de Normas Técnicas, Laje Pré-Fabricada-Painel Alveolar de Concreto Protendido - Requisitos, NBR 14861, 2011.

[3] Federation Internationale du Beton, Guide to Good Practice: Special Design Considerations for Precast Prestressed Hollow Core Floors. Lausanne: CEB-FIB, 2000.

[4] Associação Brasileira de Normas Técnicas, Projeto de Estruturas de Concreto - Procedimento, NBR 6118, 2014.

[5] Federation Internationale du Beton, Model Code for Concrete Structures. Lausanne: CEB-FIB, 1978.

[6] M. L. G. Marquesi, “Contribuição ao estudo dos mecanismos resistentes à força cortante em lajes alveolares protendidas,” M.S. thesis, Univ. Fed. São Carlos, São Carlos, 2014.

[7] J. C. Walraven and W. P. M. Mercx, "The bearing capacity of prestressed hollow core slabs," Heron., vol. 28, no. 3 , 1983.

[8] F. K. Kong, R. H. Evans, and V. M. Ohn, Reinforced and Prestressed Concrete. UK: Spon Press, 2001.

[9] R. Klein-Holte, "Shear and anchorage resistance," in IPHA Tech. Sem., Tallin, Estonia, 2017.

[10] T. Telford, Precast Prestressed Hollow Core Floors. London: Telford, 1988.

[11] F. Cavagnis, M. F. Ruiz, and A. Muttoni, "A mechanical model for failures in shear of members without transverse reinforcement based on development of a critical shear crack," Eng. Struct., vol. 157, pp. 300-315, 2018.

[12] Comité Européen de Normalisation, Eurocode 2 - Projeto de Estruturas de Betão - Parte 1-1: Regras Gerais e Regras para Edificios, EN 1992-1-1, 2004.

[13] European Concrete Platform ASBL, Eurocode 2 Comentary, 2008.

[14] K. S. Elliott, "Transmission length and shear capacity in prestressed concrete hollow core slabs," Mag. Concr. Res., vol. 66, no. 12, pp. 585-602, 2014.

[15] N. S. Fernandes, "Cisalhamento em lajes alveolares pré-fabricadas em concreto protendido: ensaio padrão de apoio para controle de qualidade,” M.S. thesis, Univ. Fed. São Carlos, São Carlos, 2007.

[16] Federation Internationale de la Précontrainte, Guide to Good Practice: Quality Assurance of Hollow Core Slab. London: FIP, 1992.

[17] B. Catoia, "Lajes alveolares protendidas: cisalhamento em região fissurada por flexão," Ph.D. dissertation, Univ. São Paulo, São Carlos, 2011.

[18] American Concrete Institute, Building Code Requirements for Structural Concrete (ACI 318-08) and Commentary, ACI Committee $318,2008$.

[19] O. Hedman, and A. Losberg, Design of concrete structures with regard to shear forces, in shear and torsion (CEB Bulletin D'Information 126). Paris, 1978.

[20] Comité Européen de Normalisation, Precast Concrete Products - Hollow Core Slabs, EN 1168, 2005.

Author contributions: BC: data curation, experimental tests, methodology, conceptualization, formal and experimental analysis, writing, and text formatting; ALR: writing conceptualization and text formatting; MAF: supervision, writing conceptualization, funding acquisition, supervision, writing and formal analysis.

Editors: Maurício de Pina Ferreira, José Luiz Antunes de Oliveira e Sousa, Guilherme Aris Parsekian. 